\title{
Judaism in the Nineteenth Century: A General Overview
}

During his lifetime, Rabbi Marcus Jastrow experienced firsthand all of the major problems and phenomena of nineteenth-century Judaism in Germany, Poland, and the United States. Before I embark on the story of his life, and above all his views on the reform or reforms of Judaism, therefore, I shall attempt to outline the main trends and characters that may have had an influence on Jastrow's views, and the major events that occurred during his lifetime in the places in which he lived.

The nineteenth century brought many changes to the history of Jews and Judaism, turning an almost homogenous society based on religious customs and laws into a socially, culturally, and religiously pluralist society. These changes began in the seventeenth and eighteenth centuries with religious crises such as mystical and messianic movements, as well as the influence of the Enlightenment and the quest for equality by sections of the Jewish community. The Haskalah, the Jewish enlightenment, had a remarkable impact on the form of nineteenth-century Judaism, and its problems. It caused a real revolution which, to varying degrees, affected the lives of Jews in all the countries of the Diaspora in Europe and the United States. The organizations, ideologies, denominations, and divisions that emerged as a result of these processes form the basis for the present state of the Jewish world. But Orthodox, Reform, and Conservative Judaism were not solely the results of processes of internal change in the Jewish community: they were also, to a large extent, results of reactions to and relations with the external world.

\section{The Haskalah and the Reform of Judaism in Germany}

At the end of the eighteenth century, arguments rooted in the ideology of the Enlightenment were voiced in France and some German states in support of the granting of equality and full emancipation to Jews. ${ }^{1}$

$1 \quad$ Eisenbach, Emancypacja Żydów, 126-135. 
Those opinions also began to gain popularity among the Jews themselves, who needed to find an appropriate reaction to the new situation and the opportunities it presented. Moses Mendelssohn, known as the "father of the Haskalah," defined the ideological framework of the Jewish response to the new era in his works and speeches. This framework constituted a compromise, including the modernization of Jewish life but not at the expense of loyalty to religious tradition, to which he was faithful until his death. However, his desire for Jewish emancipation and participation in political, social, cultural, and economic life required certain changes and compromises from the Jews. ${ }^{2}$ The attitude that Mendelssohn and the maskilim called for involved, above all, the adoption of the language of the country of residence, and the renunciation in intellectual life of Yiddish, the "shameful jargon," in favor of Hebrew, the "real" Jewish language. Jews were also to become more similar to their Christian neighbors through changes to their dress and lifestyle, and this could not be achieved without a reform of traditional Jewish education. For Mendelssohn, who considered himself a spiritual heir of Maimonides, there was no dissonance in accepting secular education and teaching - not only was this not a transgression of the law, but it was a necessity of the new era. Therefore, the advocates of the Haskalah attached great importance to Jewish schooling and education at all levels, which would include the teaching of vernacular languages and secular subjects, as well as vocational training for professions previously inaccessible to or forbidden for Jews. Another fundamental postulate advocated by the supporters of the Haskalah was loyalty toward the state and its authorities. The ideas and principles of the Haskalah movement first gained expression in the German-speaking countries and soon spread throughout Western and Central Europe and Russia. ${ }^{3}$

2 For more about Mendelssohn, see Salomon Łastik, Z dziejów oświecenia żydowskiego. Ludzie i fakty (Warsaw: PIW, 1961), 24-30; Michael A. Meyer, The Origins of the Modern Jew: Jewish Identity and European Culture in Germany, 1749-1824 (Detroit: Wayne State University Press, 1967), 11-28; and Aleksander Altman, Moses Mendelssohn: A Biographical Study (Tuscaloosa: University of Alabama Press, 1973), which also contains an extensive bibliography.

3 Cf. Shmuel Feiner, Haskalah and History: The Emergence of a Modern Jewish Historical Consciousness, trans. Chaya Naor and Sondra Silverston (London: The Littman Library of Jewish Civilization, 2002); Shmuel Feiner and 
Mendelssohn saw no discrepancy between the ideology of the Haskalah and the values of traditional Judaism. He was a true follower of Judaism for the rest of his life, though he was treated by many not as a reformer but as a heretic who did more harm than good for the Jews and Judaism. ${ }^{4}$ His students and future maskilim interpreted the emancipation and participation of Jews in social life in a number of ways. By the end of the eighteenth century, there were four movements based on different interpretations and understanding of the Haskalah.

The first consisted of emancipation being seen as merely a stage in the process of full assimilation and, consequently, departure from Judaism or even conversion to Christianity. The second movement completely rejected the Haskalah as a heresy and a road to secularization. The third was initiated by those maskilim who, like Mendelssohn, sought to reconcile the values of Haskalah with traditional Judaism. The fourth, which is the one of greatest interest to us here, was led by those followers of the Haskalah who wanted to neither abandon Judaism nor reject emancipation. They tried to find a compromise with a modernizing reform of Judaism. This reform was to consist of removing those elements of Judaism which, according to the advocates of this trend, were an obstacle to full emancipation and contact with and acceptance by their Christian neighbors. ${ }^{5}$

David Sorkin, eds., New Perspectives on the Haskalah (London: The Littman Library of Jewish Civilization, 2001); Jacob S. Raisin, The Haskalah Movement in Russia (Philadelphia: Jewish Publication Society of America, 1913); and Łastik, Z dziejów oświecenia.

His translation of the Bible into German became the symbol of the Haskalah, but at the same time, to opponents of the movement it was an example of a departure from tradition. Thus there were cases of public burnings of “Mendelssohn's Bible"; see, e. g., Majer Bałaban, Historja Żydów w Krakowie i na Kazimierzu (Krakow: "Nadzieja," 1936), vol. II, 540-541. For other religious conflicts, see also Shmuel Feiner, "Między Lesznem a Berlinem. Pierwszy spór ortodoksji z haskalą i jego religijne oraz społeczne implikacje," in Duchowość żydowska w Polsce. Materiały z międzynarodowej konferencji dedykowanej pamięci profesora Chone Shmeruka Krakow 26-28 kwietnia 1999, ed. Michał Galas (Krakow: Księgarnia Akademicka, 2000), 279-286.

Meyer, The Origins, 85-114; Michael Meyer, "Jewish Communities in Transition," in German-Jewish History in Modern Times, vol. II of Emancipation 
The movement for reform in Judaism was therefore deeply rooted in the Haskalah, though the two movements were not the same. We need to remember that in the German-speaking countries, the ideas of the Haskalah and, later, Reform Judaism reached above all communities and individuals in larger cities-Berlin, Königsberg, Hamburg, Frankfurt-where they found fertile ground. The movement's impact also depended on political and religious factors. As noted by Michael Meyer, the movement for reform in Judaism had more followers and greater influence where the Protestant Church was stronger. ${ }^{6}$ It should not come as a surprise, then, that the first attempts to introduce reforms took place in the Kingdom of Westphalia, where the law was similar to French law at the time. ${ }^{7}$ They were initiated by the consistorial president of the Jewish community in Kassel, Israel Jacobson, and were mainly aimed at adapting Judaism to the modern world through copying Protestant forms of worship. Thus the initial reforms sought to make synagogue services more attractive through the adoption of socially appropriate behavior and appearances, and the introduction of sermons, in the vernacular, which focused mostly on issues of morality and spiritual development. The first such sermon was delivered by Joseph Wolf of Dessau in 1808. In time, choral singing and organ music were introduced, and prayers recited in Hebrew were replaced by prayers in German. The role of the rabbi changed as well-he was no longer an authority and "oracle" in matters of religious law, but rather a priest and teacher of religion whose role and function was comparable to that of a pastor. ${ }^{8}$ Jacobson started delivering services in the new form in Seesen in 1810, and in Berlin when he moved there in 1815 . He established a synagogue in his home in Berlin,

and Acculturation: 1780-1871, ed. Michael A. Meyer and Michael Brenner (New York: Columbia University Press, 1997), 90-105.

$6 \quad$ Ibid., 90-127. Some scholars see a parallel between the Reformation and the Reform movement in Judaism, though it seems that such influences were quite limited. The Protestant Reformation was undoubtedly held up as an example of religious revival by Jews, cf. Michael A. Meyer, Response to Modernity: A History of the Reform Movement in Judaism (Detroit: Wayne State University Press, 1995), 17-18; Michael A. Meyer, "Judaism and Christianity," in German-Jewish History in Modern Times, vol. II, 168-198.

7 Eisenbach, Emancypacja Żydow, 126-128.

8 Meyer, Jewish Communities, 106-108. 
holding Reform services there regularly. In 1818, about 25 percent of the Jewish residents of Berlin participated in such Reform services. ${ }^{9}$ New synagogues, such the Hamburg Temple founded in 1818, resembled churches rather than old Jewish prayer houses in their décor. Although the reformers tried to make sure that the changes did not transgress traditional religious laws, the innovations threatened centuries-old customs, so naturally they were attacked by opponents of the Haskalah and the Reform movement..$^{10}$ The only non-Orthodox community at the time was the community of Hamburg, which brought out a new, bilingual, Hebrew-German prayer book ${ }^{11}$ and new synagogue by-laws. The most important modification they made to the prayer service was the elimination of those sections which mentioned the return of the Jews to the Land of Israel under the leadership of the Messiah. This change suggested that Germany, or any other country inhabited by Jews, could replace Erets Yisra'el, because the religious goal and ideals of the Jewish faith could be achieved anywhere. The word used for the synagogue-temple-was based on similar ideological attitudes, which held that the Holy Temple would not be rebuilt, but every house of prayer could be considered a temple. Early reformminded Jews were advocates of secular education, too, and their children often attended Christian schools.

At the beginning of the nineteenth century, voices were raised in favor of further changes in doctrine and worship in order to achieve the goal of emancipation and "coming out of the ghetto." David Friedländer, a student of Mendelssohn's, was the first to signal further changes in the liturgy and faith. ${ }^{12}$ However, the program of reform

$9 \quad$ Ibid., 125.

10 For more about the first attempts to introduce reforms, and their consequences, see ibid., 119-123.

11 Seder ha-Awodah. Ordnung der öffentlichen Andacht für die Sabbath-und Festtage des ganzen Jahres. Nach dem Gebrauche des Neuen-Tempel-Vereins in Hamburg (Hamburg [1819]). It is considered one of the first Reform prayer books. See Jakob J. Petuchowski, Prayerbook Reform in Europe: The Liturgy of European Liberal and Reform Judaism (New York: World Union for Progressive Judaism, 1968), 2.

12 For more about this important figure, see Meyer, The Origins, 57-84. Friedländer is also known for writing a book on Jewish reform in the Kingdom of Poland, commissioned by Archbishop Franciszek Malczewski Skarbek: David Friedländer, Über die Verbesserung der Israeliten des Königreich 
would crystalize later, during the three rabbinical conferences of Brunswick (1844), Frankfurt (1845), and Breslau (1846). ${ }^{13}$ Two trends dominated the Reform movement in Judaism during this period. One was identified with Abraham Geiger, who gained popularity and reputation first as a scholar of Jewish history affiliated with the Verein für Cultur und Wissenschaft der Juden in Berlin, and later as a leading figure of the Reform movement. He was a rabbi in Breslau for many years, and between 1872 and 1877 a lecturer at the Hochschule für die Wissenschaft des Judentums, the main rabbinical seminary and research center of Reform Judaism in Germany. Geiger's views originated in observations he made in the course of his academic research. He believed that in every era Judaism reflected the aspirations of the Jews at that time and was a reaction to existing conditions. Judaism was, therefore, an evolving religion, and changes in Judaism had always been evolutionary rather than revolutionary. The principles of his vision of Reform Judaism were included in a prayer book published in 1854 in which he omitted references to resurrection, angels, the rebuilding of the Temple, and the return to the Land of Israel. Geiger also reinterpreted the personal Messiah and messianic hope as universal, not specifically national. He rejected the idea of chosenness and many religious laws, among them the dietary laws. ${ }^{14}$

Another leading figure, this one associated with a more radical branch of the Reform movement, was Samuel Holdheim, who advocated changes in Judaism but supported a more revolutionary approach. His understanding of the Bible and the Talmud was also more radical: he held that they contained both the eternal and unchangeable values of monotheism and morality and laws and rulings that related to specific historical events and situations. Holdheim

Pohlen. Ein von der Regierung daselbst im Jahr 1816 abgefordertes Gutachten (Berlin, 1891). See Krzysztof Pilarczyk, Literatura żydowska od epoki biblijnej do haskali (Krakow: Wydawnictwo UJ, 2006), 307.

13 For more about the conferences and their resolutions, see David Philipson, The Reform Movement in Judaism ([New York]: KTAV, 1967), 140-224.

14 For more about Abraham Geiger and his doctrine, see Ken Koltun-Fromm, Abraham Geiger's Liberal Judaism (Bloomington: Indiana University Press, 2006); Abraham Geiger and Liberal Judaism. The Challenge of the Nineteenth Century, compiled with a biographical introduction by Max Wiener, trans. from German Ernst J. Schlochauer (Philadelphia: Jewish Publication Society of America, 1962). 
proposed that the latter should be removed, as they had no normative value. He rejected the Oral Torah on the basis of a belief that "the Talmud speaks out of the consciousness of its age and for that time it was right; I speak out of the higher consciousness of my age and for this age I am right." 15 In addition, Holdheim did not believe in the Messiah or the return to the Land of Israel, and he abolished the observance of the second days of religious holidays in the Diaspora. He wanted Judaism to be a universalist religion devoid of nationalistic and particularistic elements; hence, he advocated a form of worship similar to that of Christianity. He not only supported the idea that the German language should replace Hebrew as the language of sermons and prayers, but he also moved the observance of the Sabbath from Saturday to Sunday. Holdheim's radical views found few followers in Germany, and most of those few were in Berlin, though his ideology found adherents among the radical reformers in America. ${ }^{16}$

Through their education and questions about true Judaism, the advocates of religious reform and the Haskalah contributed to the emergence of an interest in academic research into Jewish history and attempts to learn about the essence of Judaism, free from the accretions of centuries. One of the first initiatives they led was the founding of the already mentioned society, the Verein für Cultur und Wissenschaft der Juden, whose main aim was to lead Judaism to selfawareness and to make the Jewish world known to the Jews. ${ }^{17}$ One of the best-known members of the society was Leopold Zunz, one of the founders of the Wissenschaft des Judentums movement, which gave rise to modern Jewish Studies. ${ }^{18}$ To the proponents of Wissenschaft des Judentums and Zunz, the goals of the movement were on the one hand to initiate research into the Jewish religious, historical, cultural, and literary heritage using contemporary scholarly methods, and on the other hand to bring that tradition into the "bloodstream" of the

\footnotetext{
15 Meyer, Response to Modernity, 83.

16 For more about Samuel Holdheim, see ibid., 77-84.

17 Meyer, Jewish Communities, 131.

18 See Michael Brenner, Stefan Rohrbacher, eds., Wissenschaft vom Judentum; Annäherungen nach dem Holocaust (Göttingen: Vandenhoeck \& Ruprecht, 2000); David Nathan Meyers, "The Ideology of Wissenschaft des Judentums," in History of Jewish Philosophy, ed. Daniel H. Frank and Oliver Leaman (London: Routledge, 1997), 706-720.
} 
German and wider European awareness as an important element of universal human heritage.

One of the crucial figures in the Wissenschaft des Judentums movement was Zacharias Frankel, who initially joined the supporters of religious reform and even took part in the first and second conferences of Reform rabbis in Brunswick (1844) and Frankfurt (1845), though he withdrew from the second conference in protest at what he considered the too far-reaching reforms proposed by Geiger and others. He was particularly opposed to the ideas of removing the Hebrew language from the liturgy and replacing it with German, and eliminating all references to messianism. Frankel believed that the core values of Judaism were "unchangeable and imperative" ${ }^{19}$ because they were derived from revelation. He held the view that it was permissible to reform customs based on the Oral Law, as the Oral Law did not come from revelation but from the sages, and was shaped over thousands of years of Jewish history and experience. As such, the Oral Law deserved respect, though changes to it were permissible. Such a stance required turning to the study of the history and collective experience of the Jews, which had had a greater formative influence on Judaism than theology had..$^{20} \mathrm{He}$ described what he was trying to achieve as "Positive-Historical Judaism."

Frankel believed that Jews constitute only a "religious, spiritual community conditioned by faith - they have an identity only inasmuch as they keep their faith. Therefore, Jews form a religious community only, like any denomination present in a given country." ${ }^{21}$

He held that every religion evolves, but any changes in Jewish rituals should be introduced in a manner that does not violate the core values of Judaism. He supported reforms that would help Jews adapt to their new conditions-primarily educational reforms. Apart from Geiger, Frankel was the best educated advocate of religious reform, and they were both candidates for the post of director and lecturer at the newly established Jewish Theological Seminary of Breslau,

19 Often referred to as "positive," cf. Meyer, Jewish Communities, 141.

20 Cf. Arthur Hertzberg, Aron Hirt-Manheimer, Żydzi. Istota i charakter narodu, transl. B. Paluchowska (Warszawa: Mada, 2001), 172. (English: Arthur Hertzberg, Aron Hirt-Manheimer, Jews: the essence and character of a people, [San Francisco]: HarperSanFrancisco, 1998.)

21 Quoted after Meyer, Jewish Communities, 145. 
founded in $1854 . .^{22}$ Eventually, it was Frankel who was elected head of the seminary, and he who shaped it and imposed on it a particular vision of teaching and academic research. Frankel also contributed to the seminary's evolution into the main center of moderate reform, which was referred to as "Positive-Historical" Judaism at the time. The lecturers at the seminary were eminent historians in various fields of study: Heinrich Graetz, Jacob Bernays, Manuel Joël, Benedict Zuckermann, David Rosin, Marcus Brann, and many others. Frankel had also been the founder in 1851 of the Monatsschrift für die Geschichte und Wissenschaft des Judenthums, the most important scholarly periodical of the "positive-historical school." 23

In the mid-nineteenth century the structure of Reform or Positive-Historical Judaism had not yet been formed. Hence, the majority of followers gathered around the most prominent individuals. However, there were also a number of figures, both rabbis and laymen, who supported the reforms without engaging in the activity of such circles, for instance Isaac Noah Mannheimer and the well-known and respected rabbi Dr Michael Sachs, who were advocates of moderate reform.

The responses of Orthodox circles to the ideology of the Haskalah and the attempts at reform varied. The Gaon of Vilna (Rabbi Elijah ben Shlomo Zalman Kremer), the Hasidic leaders, and later the leader of modern Orthodoxy, Rabbi Moses Sofer of Bratislava, were profoundly opposed to any changes in the established Jewish tradition. Sofer even went so far as to declare that anything "new is forbidden by the Torah." ${ }^{24} \mathrm{He}$ was against secular education, changes in dress, and efforts toward emancipation. Sofer pronounced the followers of the Enlightenment and Reform heretics.

The prominent German Orthodox rabbi Samson Raphael Hirsch differed from Sofer in his views, as he sought a compromise between Judaism and the modern world. He considered Moses Mendelssohn

22 The full name of the seminary was Das Jüdisch-Theologische SeminarFränckelscher Stiftung.

23. Die Monatsschrift für Geschichte und Wissenschaft des Judentums, published between 1851 and 1939, was the leading academic journal, and was copied by other propagators of Jewish studies around the world (e. g. Miesięcznik Żydowski [Jewish Monthly] published in the 1930s). 
to be an example attesting to the fact that such a compromise was possible. Hirsch held that it was the Jews, not Judaism, that were in need of reform. He thus accepted acculturation to a certain extent, particularly in terms of dress, use of the local language, and access to secular education. Hirsch's philosophy, "Torah im derekh eretz-Torah in association with "the way of the land"," involved loyalty to the values of Judaism combined with participation in the social life of the country of residence. He initially joined forces with Frankel against the radical reformers, and even expressed his willingness to become a lecturer at the seminary in Breslau. When Frankel turned him down, Hirsch distanced himself from him and started his own movement, commonly known as "Neo-Orthodoxy." 25

These are four reactions to the challenges of the Haskalah in the field of religion that were characteristic of the experiences of German Jews in the nineteenth century. Jastrow came into contact with each of these ideologies and most of their leaders, and the impacts of those contacts would echo in his future work.

\section{The Influence of Reform in Judaism in the Polish Lands}

The subject of religious reform in Judaism is often overlooked in the historiography of the nineteenth-century history of Jews and Judaism in the Polish lands, or it is discussed in a few sentences, usually accompanied by the statement that progressive ideas and the Reform movement in Judaism did not have any significant impact in this part of Europe due to the strength of Jewish Orthodoxy and Hasidism.

Michael Meyer, the most distinguished modern historian of Reform Judaism, disagrees with this view, arguing that contemporary

25 Jacob Breuer, ed., Fundamentals of Judaism: Selections from the Works of Rabbi Samson Raphael Hirsch and Outstanding Torah-true Thinkers, ed. Jacob Breuer (New York: Published for the Rabbi Samson Raphael Hirsch Society by P. Feldheim, 1969); Samson Raphael Hirsch, The Nineteen Letters, trans. Karin Paritzky, revised and with a comprehensive commentary by Joseph Elias (New York: Feldheim Publishers, 1995); Noah H. Rosenbloom, Tradition in an Age of Reform: The Religious Philosophy of Samson Raphael Hirsch (Philadelphia: Jewish Publication Society of America, 1976); and Mordechai Breuer, The "Torah-im-derekh-eretz" of Samson Raphael Hirsch (Jerusalem: Feldheim Publishers, 1970). 
historians of Judaism and Jewry have been neglectful of the history of the movement for Jewish religious reform in Central and Eastern Europe (mainly with the Polish lands in mind). He designates certain research areas which should be explored first, in order to be able to state with certainty the extent of the influence of Jewish religious reform in that part of Europe. The most crucial of these are: to locate the phenomenon of religious reform in Eastern Europe; to determine the origins of reform in the context of both the political and the intellectual milieux of Eastern European Jewry, and particularly in relation to the model of the religious reform originated by German Jews; and to assess the scope and depth of the movement's influence and the character and consequences of reform ideology in religious and secular contexts. ${ }^{26}$ Meyer's only article on Eastern Europe is limited mainly to Russia, though he does also mention the phenomenon of religious reform in the Polish lands. ${ }^{27}$ He maintains that only one small group of Jews, those in the German synagogue in Warsaw, introduced radical Reform services and sermons delivered in Polish. However, he notes, the Polish progressives, who tended to be wealthy and assimilated, were not aware of their affiliation with a worldwide movement. ${ }^{28}$ While Meyer is clearly correct about the need for more research, this judgment is flawed.

Warsaw was indeed the first Polish city to boast a "German" synagogue, which was established in $1802 .{ }^{29}$ The main centers of

26 Michael A. Meyer, "The German Model of Religious Reform and Russian Jewry," in his, Judaism within Modernity: Essays on Jewish History and Religion (Detroit: Wayne State University Press, 2001), 279.

27 It is significant that Meyer does not differentiate between Warsaw and Odessa in this respect, and he writes: "Toward the middle of the nineteenth century, "German" prayer services were established in a number of Russian cities: in Odessa, Warsaw, Riga, and Vilna." Meyer, "The German Model of Religious Reform and Russian Jewry," 281. Cf. idem, Response to Modernity, 197-198.

$28 \quad$ Ibid., 339.

29 The term "progressive synagogue" in the Polish lands corresponds with "reform" or "liberal" synagogue in Germany at that time. In AustriaHungary, reformers were also known as Neologs. See Michael A. Meyer, "Religious Reform," in YIVO Encyclopedia of Jews in Eastern Europe, www. yivoinstitute.org/pdf/reform.pdf, 2-3. See also Michał Galas, "The Influence 
reform in Judaism in the Polish lands were synagogues or houses of prayer referred to as "progressive," "reform," "German," "Polish," or as "temples." Unfortunately, in the historiography of nineteenth-century Jewish history in the Polish lands, much more attention has been devoted to the processes accompanying the Haskalah and religious reform in Judaism, i. e., to acculturation, assimilation, secularization, and integrationism, ${ }^{30}$ than to strictly religious aspects of this development. ${ }^{31}$ The few works on the impact of the religious reform movement deal mainly with the histories of individual communities or synagogues, and rarely touch upon specifically religious issues such as liturgical changes, rabbis and preachers, the contents of sermons, and modifications to services - themes that could be summarized as "what Polish progressives in the nineteenth century believed and how they expressed their religiosity." No comprehensive biographies or critical studies have been written about the great preachers and advocates of Polish-Jewish fraternization, such as Abraham Goldschmidt, Marcus Jastrow, Izaak Cylkow, ${ }^{32}$ Izaak Kramsztyk, Samuel A. Poznański, and

of Progressive Judaism in Poland: An Outline," Shofar. An Interdisciplinary Journal of Jewish Studies 29, no. 3 (2011): 55-67.

The most important publications on this subject include Tomasz Gąsowski, Między gettem a światem. Dylematy ideowe Żydow galicyjskich na przełomie XIX i XX wieku (Krakow: Księgarnia Akademicka, 1996); Scott Ury, "Pod szubienicami...". Polityka asymilacji w Warszawie przełomu wieków," in Duchowość żydowska w Polsce, ed. Michal Galas, 309-326; Stefan Kieniewicz, "Assimilated Jews in Nineteenth-Century Warsaw," in The Jews in Warsaw: A History, ed. Władysław T. Bartoszewski and Antony Polonsky (Oxford: Basil Blackwell, 1991), 151-170; Antony Polonsky, The Failure of Jewish Assimilation in Polish Lands and Its Consequences (Oxford: Oxford Centre for Hebrew and Jewish Studies, 2000).

31 Stephen D. Corrsin also points this out in his very valuable article, which is at the same time a sort of review of Meyer's works on Eastern Europe. See Stephen D. Corrsin, "Progressive Judaism in Poland: Dilemmas of Modernity and Identity," in Cultures and Nations on Central and Eastern Europe: Essays in Honor of Roman Szporluk, ed. Zvi Gitelman et al. (Cambridge, MA: Harvard University Press, 2000), 89-99.

32 On Cylkow see Michał Galas, ed., Izaak Cylkow. Życie i dzieło (Krakow-Budapest: Wydawnictwo Austeria, 2010). 
Moses Schorr of Warsaw, or Szymon Dankowicz ${ }^{33}$ and Ozjasz Thon ${ }^{34}$ of Krakow, as well as many others. Let us hope that this book prompts the filling of this gap.

The truth is that there were not many such progressive communities, and their existence was limited to larger towns, particularly those in the Prussian partition. Nevertheless, the Warsaw "German" synagogue, with which Jastrow was affiliated from 1858, existed as early as the beginning of the nineteenth century. In 1852, a "Polish" synagogue affiliated with the rabbinical school was also established there. ${ }^{35} \mathrm{In}$ addition, Progressive communities with their own synagogues existed in Łódź, Vilna, and Zhytomyr, and in Galicia in Lviv, Tarnopol, Brody,

33 On Dankowicz see Michał Galas, ed., Synagoga Tempel i środowisko krakowskich Żydów postępowych (Krakow-Budapeszt: Wydawnictwo Austeria, 2012) and Alicja Maślak Maciejewska, Życie i działałność Szymona Dankowicza (1834-1910) (Krakow-Budapeszt: Wydawnictwo Austeria, 2013).

See, e.g., Michał Galas, “Ozjasz (Jehoshua) Thon (1870-1936)-Prediger und Rabbiner in Krakau (Eine Erinnerung anlässlich seines 75. Todestages)," Judaica. Beiträge zum Verstehen des Judentums, no. 3 (2011): 311-321; Michał Galas, "Three Views of Jewish Acculturation to Polish Culture in the 19th and Early 20th Twentieth Century Krakow," in Jewish Lifeworlds and Jewish Thought: Festschrift presented to Karl E. Grözinger on the Occasion of his 70th Birthday (Wiesbaden: Harrassowitz Verlag, 2011), 245-251.

See the following to learn about progressive institutions in nineteenth-century Warsaw: Z dziejów Gminy Starozakonnych w Warszawie w XIX stuleciu, vol. I, Szkolnictwo, Warsaw 1907, 41-140; Zofia Borzymińska, Szkolnictwo żydowskie w Warszawie, 78-93, passim; Zofia Borzymińska, "Przyczynek do dziejów szkolnictwa żydowskiego w Warszawie w XIX wieku, czyli jeszcze o Szkole Rabinów," Biuletyn ŻIH 3-4 (1984): 183-196; Antony Polonsky, "Warszawska Szkoła Rabinów: orędowniczka narodowej integracji w Królestwie Polskim," in Galas, ed., Duchowość żydowska w Polsce, 287-308; Aron Sawicki, "Szkoła Rabinów w Warszawie (1826-1863)," Miesięcznik Żydowski 1-2 (1933): 244-274; Sara Zilbersztejn, "Postępowa Synagoga na Daniłowiczowskiej," Biuletyn ŻIH 74 (1970): 31-57; Alexander Guterman, "The Origin of the Great Synagogue in Warsaw on Tłomackie Street," in The Jews in Warsaw: A History, ed. Władysław T. Bartoszewski and Antony Polonsky, 182-211; Alexander Guterman, Me-hitbolelut la-leumiyut: perakim be-toldot bet ha-keneset ha-gadol ha-sinagogah be-varshah 1806-1943 (Jerusalem: Karmel 1993); Jürgen Hensel, "Wie "deutsch" war die "fortschrittliche" jüdische Bourgeoisie im Königreich Polen? Antworten anhand einiger Beispiele aus Warschau und Lodz," in Symbiose und Traditionsbruch. Deutsch-jüdische Wechselbeziehungen in Ostmittel- und Sudosteuropa (19. Und 20. Jahrhundert), ed. Hans Hecker and Walter Engel (Essen: Klartext, 2003), 135-172. 
Kraków, and Stanisławów. ${ }^{36}$ In the inter-war period, there was one in almost every big town in the Republic of Poland. Reforms were introduced by means of the German language almost everywhere, and with time German was superseded by Polish. The model for nineteenthcentury Polish progressives was the Viennese reform known as the Viennese rite, implemented by the local rabbi Isaac Noah Mannheimer and cantor Solomon Sulzer. The Viennese reform introduced moderate changes which did not violate Jewish law and were characterized mostly by decorum and esthetics in services, sermons delivered in German, and an abbreviated liturgy. ${ }^{37}$

36 For more about progressive synagogues and institutions in the Polish lands in the nineteenth century, see Majer Bałaban, Historia lwowskiej Synagogi Postępowej (Lviv: Nakł. Zarządu Synagogi Postępowej, 1937); Majer Bałaban, Historia projektu szkoły rabinów i nauki religii mojż. na ziemiach polskich (Lviv: Nakładem Przełożeństwa Zboru Izraelickiego, 1907); Hanna Kozińska-Witt, Die Krakauer Jüdische Reformgemeinde 1864-1874 (Frankfurt a.M.: Peter Lang Verlag, 1999); Hanna Kozińska-Witt, "Stowarzyszenie Izraelitów Postępowych w Krakowie 1864-74," in Duchowość żydowska w Polsce, ed. Michael Galas, 309-326; Julian Bussgang, "The Progressive Synagogue in Lwow," Polin: Studies in Polish Jewry 11 (1998): 127-153; Verena Dohrn, "The Rabbinical Schools as Institutions of Socialization in Tsarist Russia, 1847-1873," Polin: Studies in Polish Jewry 14 (2001): 83105; Efim Malamed, "The Zhitomir Rabbinical School: New Materials and Perspectives," Polin: Studies in Polish Jewry 14, 105-116; L. Streit, Dzieje synagogi postępowej w Stanisławowie (Stanisławów: Nakładem Zarządu Synagogi Postępowej w Stanisławowie, 1939); Leszek Hońdo, “Das Verhältnis der Juden in Westgalizien zur polnischen und deutschen Kultur an der Wende vom 19. zum 20. Jahrhundert," in Symbiose und Traditionsbruch, ed. Hans Hecker and Walter Engel, 81-94.

Mannheimer's activity was an exemplar for many progressive rabbis in the Polish lands. One example may be his participation, along with Catholic and Protestant clergymen, in the funeral of the soldiers who died during the Hungarian Revolution of 1848. The picture which documents that event resembles A. Lesser's painting of the funeral of 5 victims of the demonstration of 1861. Cf. Meyer, Jewish Communities, 198, illustration 23. For more about Mannheimer, see Marsha L. Rozenblit, "Jewish Identity and the Modern Rabbi: The Cases of Isak Noa Mannheimer, Adolf Jellinek, and Moritz Guedemann in Nineteeth-Century Vienna," Leo Beck Institute Year Book (1990): 103-131; David Ellenson, "The Mannheimer Prayerbooks and Modern Central European Communal Liturgies: A Representative Comparison of Mid-Nineteenth-Century Works," in his Between Tradition and Culture: The Dialectics of Modern Jewish Religion and Identity (Atlanta, GA: Scholars Press, 1994) 59-78; Robert S. Wistrich, The Jews of Vienna in the 


\section{Judaism in the United States}

Reform ideas came to America, as they had to the Polish lands, from Germany, with Jewish immigrants. In the history of the Jews in America, the period between 1820 and 1880 is referred to as "the German period," as people from German-speaking countries constituted the core of Jewish immigration to America at the time. During those years, the number of Jews increased from 6,000 in 1830 to about 300,000 in $1880 .{ }^{38}$

The influx of Jewish immigrants from Germany had an impact on changing the face of Judaism in the United States, which had hitherto been dominated by Sephardic Jewry. From then on, Ashkenazi Jews, or "German Jews," as they were called there, began to dominate and influence the customs of both old and newly established congregations. However, in the initial period, the Jews who arrived in the New World were predominantly economic immigrants striving to improve their material and social situation. They perceived America as the "promised land," where everybody was equal and free to do as they pleased. Jewish congregations were organized by communities on the basis of voluntary membership and were independent of one another. Each was governed by a board elected from among its members, and religious matters were attended to by hazanim (cantors), who also led worship.

The first rabbi in America arrived in 1840. Abraham Joseph Rice (Reiss), who came from an Orthodox community in Bavaria, became the rabbi of the Baltimore Hebrew Congregation. What was characteristic not only of Rice but of every subsequent rabbi who came to America in his era was his aspiration to lead all American Jews and to impose his own standards and practices on them. Leaders of Orthodox communities wanted to declare Rise "the chief rabbi of the United States." 39

Age of Franz Joseph (Oxford: Published for the Littman Library by Oxford University Press, 1989), 98-115; Meyer, Response to Modernity, 144-151.

See Jonathan D. Sarna, American Judaism: A History (New Haven-London: Yale University Press, 2004), 375. A good general description of this period is provided in Hasia R. Diner, A Time for Gathering: The Second Migration 1820-1880 (Baltimore-London: Johns Hopkins University Press, 1992).

39 Harold I. Sharfman, The First Rabbi: Origins of Conflict between Orthodox and Reform: Jewish Polemic Warfare in pre-Civil War America (Malibu, CA: Pangloss Press, 1988). 
Despite these hopes, the structures of the Jewish communities and their mutual independence made it impossible to establish structures similar to those in Europe. The rabbis' striving for domination caused theological conflicts and discussions on the form of Judaism in the United States and the limits of acculturation in the New World, since the mostly German Orthodox Jews acculturated relatively quickly and needed to adapt their traditional Judaism to the new conditions. Therefore, many initially Orthodox "German" communities reformed quickly. The acculturation, or rather Americanization, of Judaism ${ }^{40}$ was advocated early on by Isaac Leeser of Westphalia, the hazan of the Sephardi Congregation Mikveh Israel in Philadelphia, who introduced sermons and education in English. Leeser was also the founder and editor of the first English-language Jewish monthly magazine, The Occident and American Jewish Advocate, and founded the first rabbinical school in America. Nevertheless, he opposed radical reforms of Judaism that would violate Jewish law. ${ }^{41}$ His views were shared and his work was continued by Sabato Morais, Henry Pereira Mendes, Benjamin Szold, Alexander Kohut, Marcus Jastrow, and many other rabbis in Philadelphia, New York, and Baltimore who, in opposition to radical reforms, contributed to the establishment of the Jewish Theological Seminary in New York and the development of Conservative Judaism. ${ }^{42}$

40 See Leon A. Jick, The Americanization of the Synagogue, 1820-1870 (Hanover and London: Published for Brandeis University Press by the University Press of New England, 1992).

41 For more about Leeser, see Lance J. Sussman, Isaac Leeser and the Making of American Judaism (Detroit: Wayne University Press, 1995); Davis, Emergence of Conservative Judaism, 347-69; and Sarna, American Judaism, 77-111.

42 Davis, Emergence of Conservative Judaism; Herbert Parzen, Architects of Conservative Judaism (New York: J. David, 1964); Sidney H. Schwarz, Law and Legitimacy: An Intellectual History of Conservative Judaism, 1902-1973 (Ph.D. diss., Temple University, 1981); Daniel J. Elazar and Geffen Rela Mintz, The Conservative Movement in Judaism: Dilemmas and Opportunity (Albany: State University of New York Press, 2000); Robert Gordis, Understanding Conservative Judaism (New York: The Rabbinical Assembly, 1978); Abraham J. Karp, "A Century of Conservative Judaism in the United States," in The History of Judaism in America: Transplantations, Transformations, and Reconciliations, part I, ed. J.S. Gurock (New York-London: Routledge, 1998), 213-272; Abraham J. Karp, “The Origins of Conservative Judaism," 
On the other hand, there were signs of reforms to American Judaism as early as in the first decades of the nineteenth century. The first signals came from Charleston, Baltimore, New York, and Richmond, where congregations of Sephardi origin sought change. Then, with the influx of German Jewish immigrants the first Reform Societies were established as seedbeds of Reform congregations. The first Reform congregations to be founded were the Har Sinai Congregation in Baltimore in 1842, the Emanuel Congregation in New York in 1845, and the Chicago Sinai Congregation in 1857. The first Reform rabbis and advocates of reform were active in the United States from the 1840s. ${ }^{43}$

In 1846 Isaac Mayer Wise came to America, and he quickly became one of the most important figures in the Reform movement. In 1848 , he wrote:

The majority of our congregations in this country have been established but a few years back; they are generally composed of the most negative elements of all the different parts of Europe and elsewhere; they have been founded and are now governed for the most part by men of no considerable knowledge of our religion... ${ }^{44}$

Isaac Mayer Wise was an Orthodox Jew, educated in Bohemia, who only embarked upon his career as a Reform rabbi once he was in the United States. Before his arrival in America he lived in Prague and Vienna for some time, and it was in those two cities that he came into contact with the ideas of Reform Judaism. Upon his arrival in the United States in 1846, he was appointed rabbi of the Beth El congregation of Albany, NY. Wise immediately introduced certain innovations, such as family pews, a mixed choir, and confirmations for both boys and girls. In 1848 he made a proposal to establish an organization uniting all the congregations in America, which would follow a rite adjusted to the conditions of American Judaism. He was

Conservative Judaism 14, no. 4 (1965): 33-48; Marshal Sklare, Conservative Judaism: An American Religious Movement (New York: Shocken Books, 1972). Meyer, Response to Modernity, 225-325.

Nathan Glazer, American Judaism (Chicago: University of Chicago Press, 1972), 32. 
removed from his office as rabbi of the Beth El congregation when he publicly announced that he did not believe in the coming of a personal Messiah or in bodily resurrection. However, together with his supporters, he soon formed a new Reform congregation, the Anshe Emeth. In 1854 Wise went to Cincinnati, Ohio, where he became rabbi of the Bnai Jeshurun congregation. He remained in that post until his death in 1900. It was during his time there that Cincinnati became the center of Reform Judaism in the United States, with Wise as its "founding father." Opinion-forming magazines and periodicals such as The Israelite $^{45}$ (in English) and Die Deborah (in German) were published there. In 1855, the first rabbinical conference in the country was held in Cleveland, on Wise's initiative. His intention was for the conference to introduce "peace and unity" into American Judaism. However, it was criticized both by Conservative Jews, among them Leeser, and radical reformers, such as David Einhorn of the Har Sinai congregation in Baltimore, who had previously been Samuel Holdheim's successor as chief rabbi of Mecklenburg-Schwerin. Two strong branches of Reform Judaism, differing in their approach to the issue of traditional Jewish law and the revelation at Sinai, existed in America from that time on.

Wise sought to establish an organization that would gather all of the American congregations. He also planned to found a rabbinical school and compile a common prayer book to be used by the whole of American Jewry. In 1856, he published Minhag Amerika, a prayer book that he intended for that purpose. Even though it did not gain much support, the prayer book became an inspiration for other rabbis preparing new versions of prayer books for their congregations. ${ }^{46}$ In his papers, Wise criticized anyone who opposed his projects, such as the founding of the first national Jewish organization, and came out against any initiatives which did not further his purpose.

Wise achieved his goals, not as the leader of American Judaism but as the leader of the followers of Reform, when he founded the Union of American Hebrew Congregations in Cincinnati in 1873, and

45 The weekly was later published under the title The American Israelite.

46 The following study is evidence of how many such prayer books were compiled at this time: Sharona R. Wachs, American Jewish Liturgies: A Bibliography of American Jewish Liturgy from the Establishment of the Press in the Colonies through 1925. Historical Introduction by Karla Goldman, Liturgical Introduction by Eric L. Friedland (Cincinnati: HUC Press, 1997). 
a seminary for training rabbis - the Hebrew Union College - in 1875. He was the first president of the college, and in 1889 became president of the Central Conference of American Rabbis, the principal organization of Reform rabbis. ${ }^{47}$ These institutions did not embrace the whole of American Jewry, as was Wise's dream, but they did give rise to the formation of Reform Judaism in the United States.

A consequence of this was the emergence of certain ideas in opposition to Reform Judaism, which developed into separate institutions marking the beginning of Conservative and Orthodox Judaism in America. ${ }^{48}$

This short overview aims to show how the face of Judaism changed within a short period of time in the nineteenth century, influenced by the advocates of religious reform in the countries in which Jastrow was active. Naturally, the Reform movement took varying forms and had differing impacts in different countries, due not only to internal opposition but mainly to diverse laws which either permitted the founding of independent Reform communities or congregations or forbade it. The movements and characters delineated above will accompany us in subsequent parts of this book.

47 James G. Heller, Isaac M. Wise: His Life, Work and Thought (New York: Union of American Hebrew Congregations, 1965); Sefton D. Temkin, Creating American Reform Judaism: The Life and Times of Isaac Mayer Wise (LondonPortland, OR: The Littman Libarary of Jewish Civilization, 1998).

48 Marc Lee Raphael, Profiles in American Judaism: The Reform, Conservative, Orthodox, and Reconstructionist Traditions in Historical Perspective (San Francisco: Harper \& Row, 1988). 
